\begin{abstract}
Summary
This paper appraises the major options for the achievement of national targets for the reduction of teenage smoking in Western countries, which has changed little in recent years. The criteria for appraisal include efficacy, cost to the health sector, reach (that is, replicability), and impact (the combination of reach and efficacy). The major interventions appraised include school health education, media and school programmes for youth, media and community programmes for all age groups, prevention of sales to teenagers, restrictions on smoking in schools, advertising bans, fiscal policy, and media advocacy. Interventions aimed primarily at youth are likely to have a delaying effect only, and sophisticated school programmes, though potentially valuable, have proved difficult to implement effectively on a large scale. Priority should therefore be given to broad-based interventions aimed at the community as a whole, including mass campaigns for all age groups, fiscal policy, restrictions on smoking, and bans on advertising. Mass campaigns may be more effective than schools at reaching high risk groups. A continuous programme of media advocacy is essential to secure both the initial allocation and the retention of the resources required for an effective national programme.
\end{abstract}

(Tobacco Control 1995; 4 : 266-277)

Keywords: smoking; children; prevention; review

Association for Public Health, Hamilton House, Mabledon Place, London WC1, United Kingdom DJ Reid

Health Education Authority, Hamilton House, Mabledon Place, London WC1, United Kingdom AD McNeill National Cancer Institute, Bethesda, Maryland, USA

TJ Glynn

Correspondence to: $\mathrm{Mr}$ Donald J Reid, Association for Public Health, Hamilton House, Mabledon Place, London WC1H 9TX, United Kingdom

\section{Reducing the prevalence of smoking in youth in Western countries: an international review}

\author{
Donald J Reid, Ann D McNeill, Thomas J Glynn
}

lations rapidly, in the light of the authors' experience as directors of national programmes. Less weight is given to those which are effective only within small communities or in well-resourced pilot trials - although these make up the bulk of the published studies on

\section{Smoking initiation}

In North America and Western Europe, most adult smokers report taking up regular smoking between the ages of 13 and $15^{5}$; and one in four teenagers have become regular smokers by the age of $15 .^{6}$ In some countries - for example, the USA ${ }^{7}$ and England ${ }^{8}-$ up to $70 \%$ of children have experimented with smoking by the age of 16 . For some teenagers, dependence on nicotine soon becomes important $^{9}$; but even so, progression to regular smoking often involves several periods of cessation and reinitiation. ${ }^{9,10}$

\section{WHY DO CHILDREN TAKE UP SMOKING?}

Several factors have been associated with the onset of tobacco use. ${ }^{4}$ Environmental factors include availability of cigarettes, the perception that tobacco use is the norm, peer and sibling attitudes, and lack of parental support during adolescence. However, the influence of parental smoking is not clear: of the published prospective studies, only about half show a clear predictive relation between teenage and parental smoking. ${ }^{4}$

Behavioural predictors ${ }^{4}$ include low academic achievement, rebelliousness, alienation from school, and lack of skills to resist offers of cigarettes. Personal risk factors include low self esteem and the belief that smoking confers future advantages in social life; but knowledge of the health risks does not by itself influence recruitment to smoking. ${ }^{11}$

Although low socioeconomic status (SES) is strongly associated with adult smoking in many, though not all, ${ }^{12}$ countries, it is less clearly associated with teenage smoking. For example, no relation was found between SES Authority (HEA) survey of 10000 English 9 to 15 year olds ${ }^{13}$; however, increased quitting by higher income smokers in England leads to an SES differential by the age of $30 .^{14}$

While smoking prevalence among boys is significantly higher where traditional gender roles prevail (for example, in Japan ${ }^{15}$ ), prevathis subject. and smoking prevalence in a Health Education

$=$

$\dot{x}$

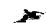

.

s principal followed by an appraisal of the drawn chiefly from North America, Western (ningdom ${ }^{2}$ ) for the reduction review of the process of smoking Europe, and Australasia. The findings cannot be applied elsewhere with confidence.

While the conclusions are broadly similar to recent United Kingdom ${ }^{3}$ and $\mathrm{US}^{4}$ reviews, greater emphasis is given here to interventions which are capable of influencing large popu-

Introduction
The purpose of this review is to identify the most effective interventions for the achievement of national targets (as in the USA ${ }^{1}$ and 

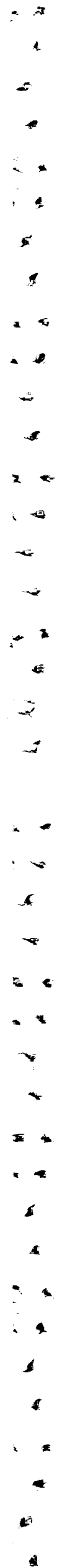

lence at age 16 is higher among girls in many Western countries. ${ }^{16}$ Explanations include physical reasons such as earlier maturation, ${ }^{16,17}$ greater susceptibility to nicotine addiction, ${ }^{10}$ and the differential impact of stress. ${ }^{18}$ Societal reasons include different experiences of adolescence, ${ }^{19}$ such as different rates of participation in sport. ${ }^{7}$ Other factors include the belief, much exploited by the tobacco industry, ${ }^{18}$ that smoking promotes weight loss. ${ }^{20,21}$

\section{CURRENT TRENDS}

Smoking prevalence among 11 to 16 year olds in many Western countries has historically followed adult patterns. Boys' smoking in the 1960s was usually higher than girls', but then fell while girls' rose, until equality was reached between 1975 and $1985 .^{22-25}$ Since then, teenage prevalence has changed relatively little in many countries ${ }^{4,8,26-28}$ despite concurrent declines in adult prevalence. However, prevalence among Canadian 15 to 19 year olds fell by two thirds from 1979 to $1991^{29}$ and a $19 \%$ decline occurred among Australian 15 year olds between 1984 and $1990 .^{30}$ Black teenage prevalence in the USA has apparently declined, for reasons which include underreporting ${ }^{31}$ but are not otherwise understood.

\section{Intervention strategies}

This review appraises two different types of intervention: health promotion options, for example, the use of health education to promote changes in individual lifestyles, and health policy options, for example restrictions on smoking in schools, use of fiscal policy, etc. These are appraised against the following criteria, as appropriate:

- efficacy-extent of any effect on teenage smoking prevalence

- costs to the health sector, that is, to national or local departments of health (in US\$) - the figures quoted may apply only to the country of origin

- reach-proportion of the target population likely to be reached by the intervention

- impact - the combination of efficacy and reach $^{32}$ (for example, cessation clinics have high efficacy in terms of quitting rates but reach relatively few smokers, so their impact is low $^{33}$ ).

Analyses of this kind can be criticised for trying "to unravel gossamer with boxing gloves" 34 because they ignore the synergy between interventions. While this is an important issue, no health department can afford to invest in every possible intervention. This review is intended to help identify the most cost-effective selection available.

Health promotion options

SCHOOL HEALTH EDUCATION

Types of programme: tobacco-specific versus comprehensive

Evidence for the efficacy of school health education is available from controlled trials of two kinds of programme: tobacco-specific, which focus mainly on smoking, and comprehensive, which deal with broader issues such as personal relationships and substance abuse generally. Some data are also available from cohort and cross-sectional studies on the relationship between smoking prevalence and school variables such as health education.

\section{Efficacy : tobacco-specific programmes}

The efficacy of tobacco-specific programmes has been the subject of considerable controversy. Early results were not encouraging ${ }^{35}$ but the development of interventions based on social learning theory ${ }^{36}$ from 1980 onwards led to a decade of optimism. This has faded only recently in the face of discouraging results under real life conditions.

Under the artificial conditions required for internal validity, tobacco-specific programmes typically delay the onset of smoking for up to five years, ${ }^{37,38}$ resulting in falls of $30-50 \%$ in smoking prevalence relative to controls by the age of $16^{39-42}$ Since there is little effect on teenagers who have already taken up smoking, best results are obtained from programmes delivered at about the age of 11-13. ${ }^{42}$

The most effective programmes focus on social reinforcement, especially the development of skills to resist the pressure to use cigarettes. ${ }^{42}$ Methods used have included role play, practising refusal skills, making public commitments not to smoke, and the use of older peers (for example, 16 year olds) to teach 12 year olds. ${ }^{43,44}$ Programmes which focus more on social norms, self esteem, and reducing alienation, with a minimal focus on drugs (including cigarettes), are also effective, but to a lesser extent. ${ }^{42}$ Factually based programmes increase knowledge, but have little effect on behaviour. ${ }^{42,45}$ Finally, while most studies report no difference in results by gender, two programmes had no effects on girls $^{44,46}$ while one had more impact on girls. ${ }^{47}$

Most of these generally favourable results have been reported from pilot programmes implemented under artificial conditions, for example, using externally recruited instructors instead of classroom teachers. ${ }^{38,48}$ This has led to criticisms of their potential for large scale replication, ${ }^{49,50}$ as predicted by diffusion of innovation theory. ${ }^{51}$ Unfortunately these criticisms have been justified by randomised controlled trials in the USA, ${ }^{52}$ the United Kingdom, ${ }^{53}$ and Australia, ${ }^{47}$ which found that programmes of this type are relatively ineffective under real life conditions.

\section{Efficacy : comprehensive health education programmes}

Comprehensive programmes should be more effective than specific programmes in dealing with adolescent behaviours with a common social genesis - such as addictions. ${ }^{54}$ Controlled trials of the comprehensive school health curriculum project (SHCP) of the US Centers for Disease Control and Prevention $(\mathrm{CDC}),{ }^{55}$ and similar programmes for ages 
$6-12,{ }^{56,57}$ all found small reductions in experimental smoking at age 12 .

Evaluation of CDC's comprehensive "teenage health teaching modules" (THTM) programme for ages $12-18$, which is "organised by ... health tasks of concern to adolescents, rather than by content area", 58 found a variety of self reported positive effects, including reductions in smoking prevalence and consumption among older teenagers (aged 15-18) at four month follow up. ${ }^{59-61}$ Many of the positive outcomes occurred among schools which implemented teenage health teaching modules under real life conditions-for example, without any specific training; however, provision of training enhanced the effects, ${ }^{62}$ as occurred also with the school health curriculum project. ${ }^{55}$

Both the SHCP and THTM studies gave priority to external over internal validity, and are therefore difficult to interpret. However, it does seem probable that programmes such as these may have modest, probably short term, favourable effects on teenage smoking, as well as other health related behaviours.

\section{Efficacy: other studies}

The findings from cohort and cross sectional studies have been mixed. A 1974-81 cohort study in Derbyshire, United Kingdom, found smoking prevalence at age $18-19$ to be $30 \%$ lower in schools where "traditional" health education was provided. ${ }^{63}$ However, in California, no association was found between student recall of antismoking classes and susceptibility to smoking in the future, though there was an association with asking a friend not to smoke. ${ }^{64}$

An Australian study of 26000 students in 347 secondary schools found that higher smoking prevalence was associated with the presence of a smoking education programme and a specialised health education teacher, ${ }^{65}$ probably owing to recognition of the need for additional provision by high prevalence schools.

Finally, lessons given in primary schools may help to reduce parents' smoking, ${ }^{66}$ while the active involvement of parents can magnify the effectiveness of school programmes for preadolescent children. ${ }^{67,68}$

Costs

The costs of providing school health education are usually met by the education sector, but additional funding from health departments may help to provide the preimplementation training essential for the more sophisticated programmes. ${ }^{69}$ However, intensive training does not necessarily achieve better behavioural outcomes than brief training. ${ }^{70}$

Reach

Although school programmes can reach the great majority of children at minimal cost to health services, ${ }^{71}$ there is a trade off between efficacy and reach-the potentially most effective programmes are those least likely to be widely adopted. For example, one year after training, only $25 \%$ of Los Angeles teachers were still using a sophisticated substance abuse prevention programme. ${ }^{70}$

In addition, few schools can provide the minimum time required for effective use of tobacco specific programmes (estimated as 6-7 hours at age $12,{ }^{72}$ with a possible requirement for "booster" sessions in later years ${ }^{40}$ ). For example, schools in western Sydney, Australia, provide an average of two lessons annually per school year in the crucial 12 to 14 year old group $^{73}$ - compared to the minimum of five recommended by the National Cancer Institute (NCI) in the USA. ${ }^{40}$ In the USA itself, competition from other "crisis" issues such as AIDS or illegal drugs limits the time available for tobacco-specific programmes. ${ }^{52,74}$ Comprehensive programmes are always likely to be more popular, especially as teachers generally rank smoking below other health topics in order of priority. ${ }^{75}$

\section{Conclusions}

The best school health education programmes appear to be capable of delaying, but not preventing, recruitment to smoking. Delay is likely to result in gains to health because later starters may stop smoking earlier, and so are at reduced risk from smoking related disease. ${ }^{76,77}$

Sophisticated tobacco specific programmes, though potentially the most effective, are unlikely to be widely adopted, and are probably less effective than pilot studies suggest. Comprehensive programmes are likely to achieve greater reach, although less is known about their efficacy. Health departments should therefore focus on support for comprehensive programmes within the broader concept of the health promoting school, with its emphasis on self esteem, health promoting policies, and family and community links. ${ }^{78}$

SCHOOL BASED SMOKING PREVALENCE STUDIES

Programmes to reduce teenage smoking should always start with a prevalence study to assess need; but school smoking prevalence studies can also be a useful intervention in themselves. For example, a survey of 45000 teenagers in the Trent region of England, followed by immediate feedback to the schools involved, led to an increased antismoking activity in both schools and community. ${ }^{79}$ Small scale surveys can be carried out by school nurses ${ }^{80}$; provided anonymity is guaranteed, biochemical validation is not essential. ${ }^{8}$

The information obtained may be useful both for curriculum planning and as a source of data for use in lessons. For example, because teenagers generally overestimate the prevalence of smoking among their peers, ${ }^{81}$ survey results may help to correct misleading impressions. ${ }^{82}$ The inclusion of questions about minor respiratory illness may sometimes reveal a direct link between smoking and health, ${ }^{83}$ thus providing further data for discussion. 


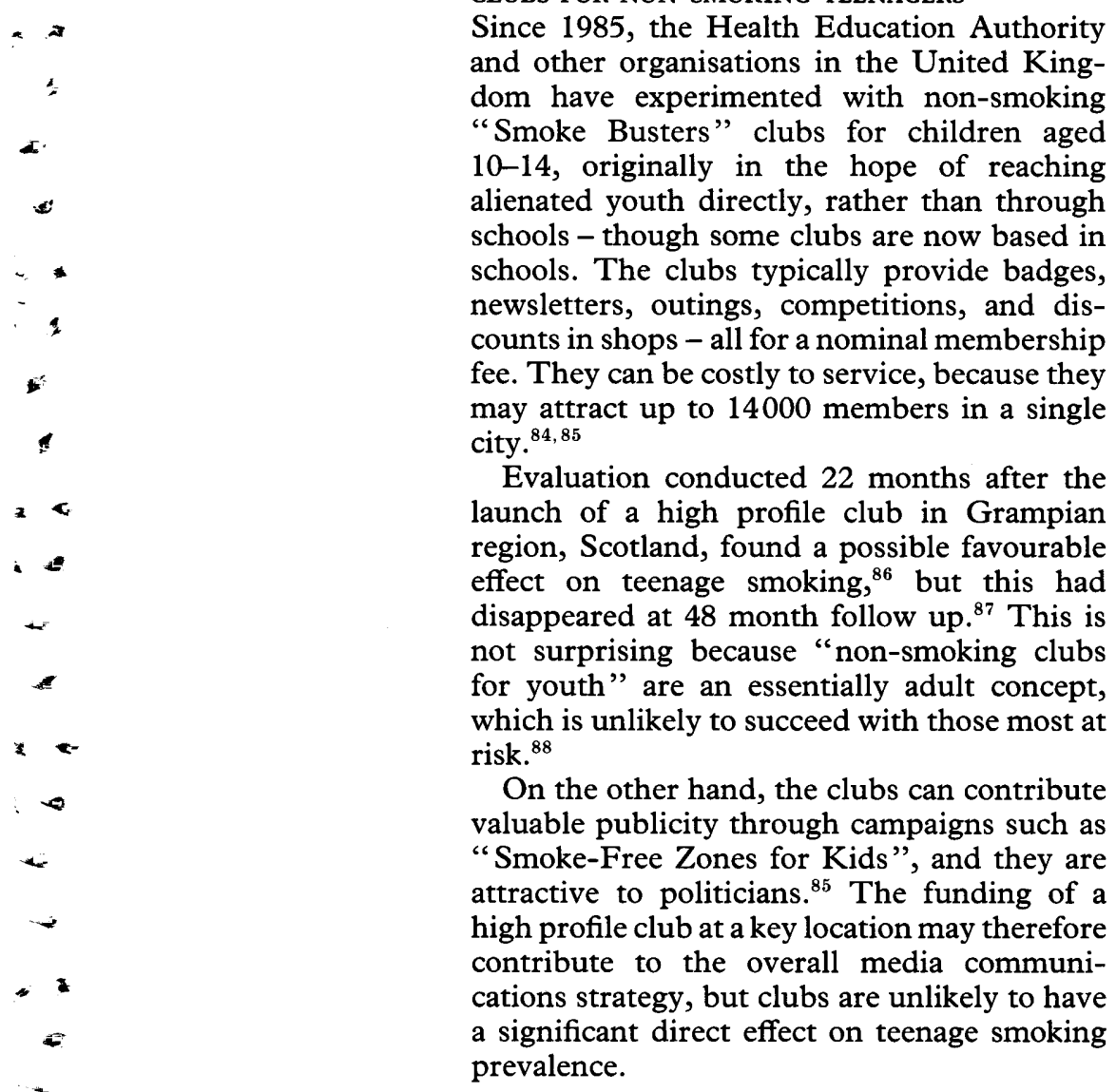

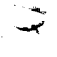

CLUBS FOR NON-SMOKING TEENAGERS

Since 1985, the Health Education Authority and other organisations in the United Kingdom have experimented with non-smoking alienated youth directly, rather than through schools - though some clubs are now based in schools. The clubs typically provide badges, fee. They can be costly to service, because they may attract up to 14000 members in a single city. 84,8 region, Scotland, found a possible favourable effect on teenage smoking, ${ }^{86}$ but this had disappeared at 48 month follow up. ${ }^{87}$ This is for youth" are an essentially adult concept, which is unlikely to succeed with those most at "Smoke-Free Zones for Kids", and they are contribute to the overall media communiprevalence.

\section{CESSATION PROGRAMMES FOR TEENAGERS}

Efficacy

Although most adolescent smokers report that they have tried to stop, ${ }^{8}$ cessation programmes have not been generally successful: "adolescent smokers are not responsive to programs thus far developed". 4 This is partly explained by the erratic development of teenage smoking, in which periods of abstinence and reinitiation typically alternate, according to United Kingdom ${ }^{9,10}$ and German studies. ${ }^{89}$ Since 18 to 21 year old smokers are twice as likely to relapse as adults, ${ }^{90}$ many leading clinicians will not accept teenagers for treatment (Fagerström KO, personal communication, 1993).

\section{Costs}

Costs are likely to be similar to adult programmes, although cost-effectiveness will be poorer for the reasons given above. Adult cessation programmes are not usually costeffective (for example, $\$ 235$ per quitter for cessation classes compared to $\$ 22$ per quitter for a self help kit, at 1981 prices $^{91}$ ) - though much cheaper than treatment for smoking related disease.

\section{Reach}

Even if the problems of efficacy can be overcome, the reach of teenage cessation programmes is limited. ${ }^{4}$ For example, a six session lunch hour programme attracted only $12 \%$ of eligible smokers in an Australian study ${ }^{92}$; only $1.3 \%$ of the eligible total were abstinent one week after the programme's quit date, and $80 \%$ of these are likely to have relapsed within six months. ${ }^{77}$ While higher reach was achieved when programmes were held during lessons, quit rates were no greater. ${ }^{92}$

\section{Conclusions}

Cessation programmes for teenagers are unlikely to have a significant impact on teenage smoking prevalence, owing to low efficacy and poor reach. Until further research ${ }^{92}$ proves otherwise, they should not be supported by health sector funds. Better options include cessation programmes for teachers - because smoking teachers make unenthusiastic health educators ${ }^{93}$ - or the giving of brief, opportunistic advice to adolescents by family doctors. ${ }^{94}$

\section{COMBINED SCHOOL AND MASS MEDIA}

INTERVENTIONS AIMED MAINLY AT YOUTH

It has long been known that the mailing of mass campaign materials to schools can lead to an increase in the time allotted to smoking education. ${ }^{95}$ Several attempts have also been made to influence young people through various combinations of school programmes and paid mass media advertising aimed mainly at youth.

\section{Efficacy}

The first of two NCI funded controlled trials found that a paid advertising campaign alone had little effect on smoking behaviour, though some favourable changes occurred in mediating variables. ${ }^{96}$

The second, based at the University of Vermont, found that a combined mass media and school curriculum intervention achieved $35-40 \%$ reductions in smoking prevalence at age 15-17, compared to school curriculum only. The effects lasted for at least two years after the intervention was complete, ${ }^{97}$ especially with high risk youth (Flynn BS, et $a l$ : paper presented at 121 st Annual Meeting of the American Public Health Association, 1993).

Unfortunately, there is less encouraging evidence from larger scale campaigns such as the Minnesota State prevention programme, which included a mass campaign aimed mainly at youth, ${ }^{98}$ funding for school programmes, and restrictions on smoking in public. $^{52} \mathrm{~A}$ three year follow up found no significant effect compared to Wisconsin, ${ }^{52}$ although Minnesota children received many more anti-smoking messages from the media than did Wisconsin children. ${ }^{99}$

Similarly, in England, major teenage programmes have been conducted since 1980, mainly through the Health Education Authority. These have included paid advertising, support for school health education, restrictions on smoking in schools, action against sales to those under 16, and the creation of 
publicity in teenage media. ${ }^{100}$ The programme was associated with a decline in the number who had tried smoking by age 11 , from $44 \%$ in 1982 to $32 \%$ in $1992 .{ }^{8}$ However, no significant change in the prevalence of regular smoking among 11 to 16 year olds in England occurred from 1982 to $1992,{ }^{8}$ although during this period adult prevalence fell from $35 \%$ to $28 \%{ }^{5}$

\section{Costs}

The cost of these initiatives was considerable. The mass media component of the Vermont project alone (including production and purchase of media) cost $\$ 0.50$ annually per head of total population (250000), variously estimated as $\$ 233^{4}$ or $\$ 656-\$ 1351,{ }^{101}$ per "delayed smoker". The costs for the entire Minnesota and English programmes (schools as well as media) were, respectively, $\$ 0.50$ per head annually for a population of four million, ${ }^{52}$ and $\$ 0.06$ per head for 48 million.

Reach

The mass media based component of these interventions can reach at least $90 \%$ of the target audience within a few months. ${ }^{98}$ However, the reach of the Vermont project is likely to be limited by its high cost and its sophisticated school component, which required an average of nearly four class periods each year for five years.

\section{Conclusions}

These results are not easy to interpret. The Vermont project was highly effective in delaying recruitment, but is unlikely to be widely adopted. Furthermore, the disappointing results from the Minnesota state programme ${ }^{52}$ suggest that a Vermont-style intervention may be less effective under real life conditions.

COMMUNITY-WIDE PROGRAMMES AIMED AT ALL AGE GROUPS

Doubts concerning the effectiveness of school programmes in isolation have led to trials of their effectiveness as part of broader community interventions to prevent coronary heart disease in the USA and Finland. Interventions for youth have also formed part of major campaigns for all age groups in Australia and California.

\section{Efficacy}

Sophisticated school programmes, when implemented as part of broader interventions including mass campaigns for all age groups, activities in the workplace, etc, resulted in $10 \%$ reductions in teenage smoking prevalence in both Minnesota and north Karelia. These lasted for at least six years in Minnesota, ${ }^{102}$ and for eight years in Karelia, ${ }^{48}$ disappearing at 15 year follow up (Vartiainen E, et al: paper presented at 9th World conference on Tobacco and Health, Paris, 1994). It is not clear whether the effect was due to a combination of the school and community programmes, or the community programmes alone. The broadly similar Stanford, California, "Five cities project" had no effect on teenage smoking. ${ }^{103}$

On a much larger scale, statewide programmes in Australia involving paid media cessation campaigns, media advocacy, advice from health professionals, workplace restrictions, and curriculum and media interventions for youth coincided with a $19 \%$ decline in smoking prevalence at age 15 between 1984 and $1990 .^{30}$ However, cause and effect cannot be attributed with certainty in the absence of controlled trials, and the broadly similar California State campaign since 1989 has so far had little effect on teenage smoking, despite substantial declines in Californian adult smoking since $1988 .^{104}$

\section{Costs}

The Sydney, Australia, Quit for Life campaign, which was primarily aimed at adults, ${ }^{105}$ had a budget of US $\$ 0.20$ per head of total population in 1983. The California programme, funded from increased cigarette taxes, cost about $\$ 0.50$ per head of total population for the media campaign and $\$ 1$ per head for school programmes. ${ }^{104}$

\section{Reach}

The reach of the coronary heart disease interventions is again likely to be limited by the sophisticated nature of the school components. However, the Australian campaigns probably achieved near universal reach, especially as the rate of decline in adult smoking accelerated significantly from 1983 onwards. ${ }^{106}$ The media component of the Californian campaign reached over two thirds of the state's adolescents. ${ }^{104}$

\section{Conclusions}

The results from some of the controlled trials in this category have proved particularly long lasting - not surprisingly in view of the concurrent community activity to discourage smoking among adult role models. Even so, the community coronary heart disease projects have limited application in real life, while the large scale campaigns in Australia and California were costly to implement-and ineffective with youth in California. Even in Australia, the decline in youth smoking cannot be attributed to the community programme with certainty, and may have ceased altogether in $1993 .{ }^{107}$

\section{Health policy and related options}

RESTRICTIONS ON SMOKING ON SCHOOL PREMISES AND ELSEWHERE

Bans on smoking by students in school have long been associated with reductions in both the prevalence of smoking and the consumption of cigarettes in France ${ }^{108}$ and California, ${ }^{109}$ while the practice of permitting older students 


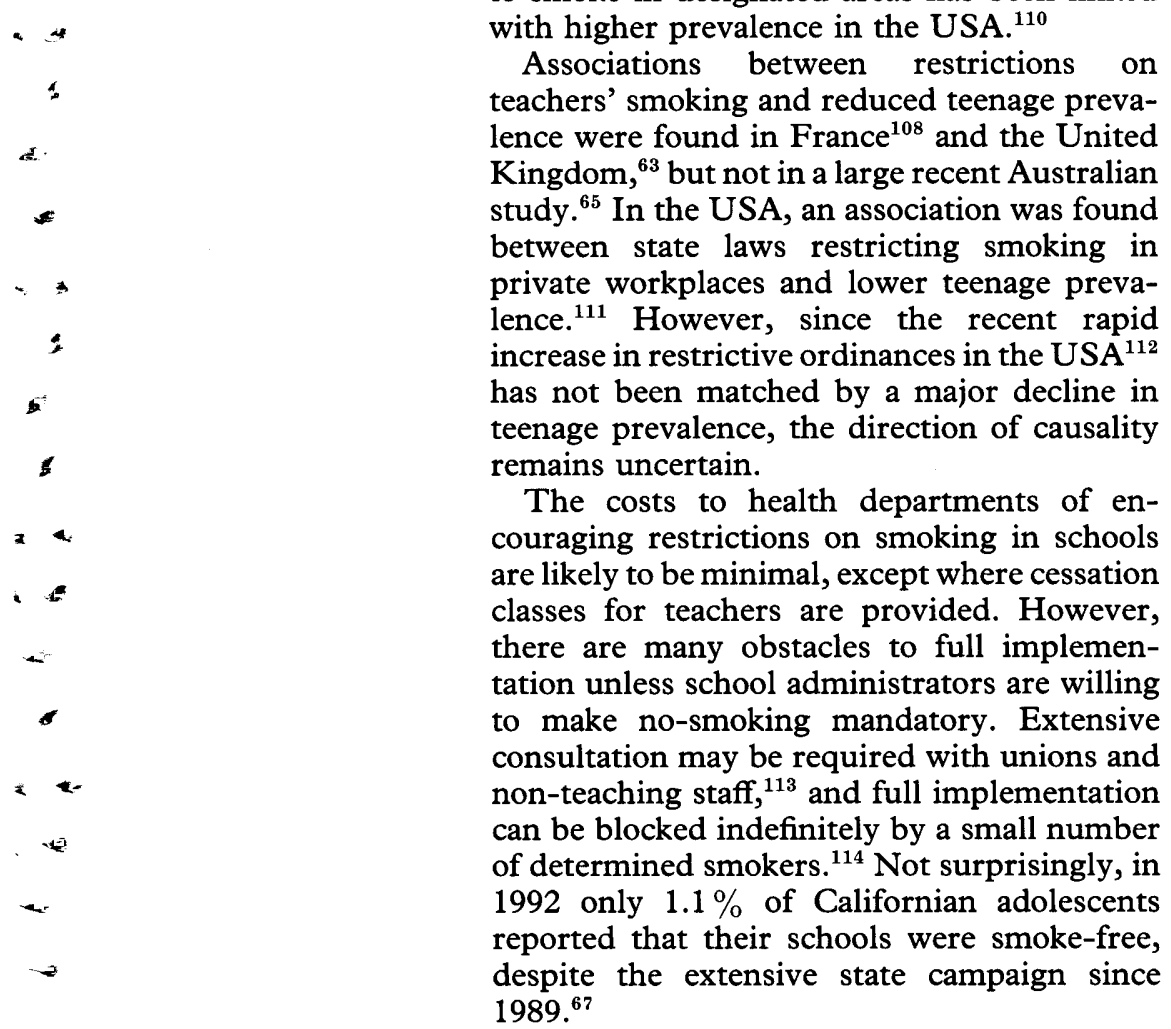

$=$

$\leftarrow$

$-$

3

:

$\checkmark$

$c$ to smoke in designated areas has been linked with higher prevalence in the USA. ${ }^{110}$

Associations between restrictions on teachers' smoking and reduced teenage prevastudy ${ }^{65}$ In the USA, an association was found between state laws restricting smoking in workplaces and lower teenage prevahas not been matched by a major decline in teenage prevalence, the direction of causality are likely to be minimal, except where cessation classes for teachers are provided. However, there are many obstacles to full implementation unless school administrators are willing to make no-smoking mandatory. Extensive a small number of determined smokers. ${ }^{114}$ Not surprisingly, in 1992 only $1.1 \%$ of Californian adolescents despite the extensive state campaign since $1989 .^{67}$

\section{Conclusions}

It is obviously desirable that the education sector (as with the health sector) set an example by establishing non-smoking as the norm on all occasions-even though there may be little effect on youth smoking prevalence. However, this may be difficult to achieve by consent, and requires firm support from school administrators for rapid implementation.

\section{RESTRICTIONS ON SALES TO TEENAGERS}

The sale of cigarettes to children aged under 16 or 18 is illegal in many countries, and both purchase and possession of cigarettes by teenagers is an offence in some parts of the USA. However, legislation of this kind is often so weakly enforced that its effects are statistically insignificant ${ }^{111}$; for example, unsupervised vending machines may provide a major loophole. ${ }^{115}$ The enactment of regulations is therefore only a symbolic first step; compliance

\section{Efficacy}

Educational campaigns and vigorous action by enforcement agencies have reduced sales to children in specific locations in the United Kingdom ${ }^{116}$ and the USA. ${ }^{115}$ However, campaigns alone-even those involving the media-do not achieve significant, lasting reductions in sales, though they may stimulate debate and so influence public opinion in favour of more effective strategies. ${ }^{117,118}$

In some small US communities, the use of underage children to make test purchases, combined with regular inspections and a law banning underage possession, has been is the key issue. associated with falls of up to $50 \%$ in teenage smoking prevalence. ${ }^{119-121}$ The duration of effect beyond the age when sales are illegal is not known. ${ }^{115}$ However, national surveys paint a more depressing picture. In North America, teenagers were able to purchase cigarettes illegally in $77 \%$ of city locations surveyed. ${ }^{122}$ In the United Kingdom, despite active campaigns and increasingly restrictive legislation, overall ease of purchase by minors has changed little since $1986 .{ }^{8}$ There has also been a threefold increase since 1982 in England in the incidence of purchasing by teenagers from "other people", presumably older teenagers or adults purchasing legally on behalf of minors. ${ }^{8}$

\section{Costs}

The costs of enforcement do not usually fall upon health departments but the opportunity costs to other sectors may be considerable - for example, up to eight hours of police officer time is required to investigate and report on an offence in California. ${ }^{17}$ The cost of a quarterly compliance check in the USA is estimated at $\$ 35$ per establishment - a sum which could be recouped by charging license fees to retailers. ${ }^{122}$

\section{Reach}

Because regular checks are essential for compliance, ${ }^{119}$ the reach of this intervention depends on the priority assigned to it by local enforcement agencies, which is likely to vary widely.

\section{Conclusions}

Vigorous activity may well help to delay recruitment to smoking among 11 to 13 year olds, but is less likely to be effective with older teenagers in the absence of strictly enforced regulations. Even then, delay is probably the most that can be achieved through this means.

The possibility that restrictions may do more harm than good by creating a "forbidden fruit" effect cannot be entirely excluded, especially as there are no legal restrictions on sales to teenagers in some countries (for example, Sweden). Nevertheless, given the possible delay to recruitment, sales to teenagers should continue to be restricted until there is firm evidence to the contrary. ${ }^{123}$ However, the legislation should penalise the vendor rather than the buyer, and should not criminalise teenage smokers by prohibiting possession. ${ }^{124}$

\section{BANS ON ALL FORMS OF CIGARETTE}

\section{ADVERTISING AND PROMOTION}

Cigarette advertising has a substantial influence on teenage attitudes to smoking, helping to convey an impression of smoking as a normal and socially acceptable activity ${ }^{4}$; but evidence for direct effects on behaviour is more difficult to find. ${ }^{125}$ Nevertheless, a cohort study of British teenagers found that "tobacco advertising promotes smoking among young 
people... though the effect appears to be small in comparison with...the other influences on children". ${ }^{10}$

However, advertising campaigns which appear to be deliberately targeted at teenagers may be more harmful. For example, peaks in smoking initiation rates among girls aged under 18 between 1944 and 1988 in the USA coincided with the launch of major advertising campaigns targeted at women. ${ }^{126}$

Similarly, although smoking prevalence among 16 to 18 year olds in California fell by one percentage point annually from 1984 to 1988 , after the introduction of the "Joe Camel" advertising campaign in $1988,{ }^{127}$ it rose by 0.7 percentage points annually from 1988 to $1990 .{ }^{104}$ In the north of England, the Health Education Authority found a possible association between increased prevalence among 11 to 15 year olds and the launch of a campaign ("Reg") which proved popular with teenagers - but not with the 35 to 55 year old adults at whom it was supposedly aimed. ${ }^{128}$

A ban on advertising has universal reach, especially if linked with a requirement to sell cigarettes in plain packaging. ${ }^{129}$ Costs to the health sector are minimal, apart from the media advocacy required to achieve it, and studies to monitor implementation. Because cigarette advertising promotes consumption among adults, ${ }^{125}$ the duration of effect is likely to be lengthy.

\section{Conclusions}

There are many reasons for advocating a complete ban on all forms of tobacco promotion. However, its achievement should not mark the completion of national campaigns, ${ }^{27}$ because it is only one of many components of an effective programme.

The continuing association of smoking with influential media personalities, for example in British youth fashion magazines, ${ }^{130}$ British $^{131}$ and American ${ }^{132}$ films (sometimes with tobacco industry funds ${ }^{133}$ ), or in British soap operas, undoubtedly influences youth. ${ }^{17}$ National health departments should therefore consider allocating resources to monitor and publicise potentially damaging depictions of smoking in the media.

\section{FISCAL POLICY}

The price elasticity of cigarettes in many industrial countries is typically about $-0.5 \% \%^{134}$ - that is, for every $1 \%$ increase in real price, per capita consumption falls by $0.5 \%$. In the United Kingdom, the effect is inversely related to socioeconomic status, so price has little effect on wealthier smokers. ${ }^{134}$

It is not clear whether young people are more sensitive to price than adults. In Canada, increased cigarette taxes between 1980 and 1988 were associated with a fall in smoking prevalence among 16 to 19 year olds from $45 \%$ to $22 \%{ }^{29}$ In the United Kingdom and the USA, the most recent studies indicate that price has similar effects on consumption by adults and youth ${ }^{134,135}$; British teenage girls are particularly sensitive to price. ${ }^{134}$

To be effective, price increases must not only exceed the rate of inflation, but must also outpace increases in real disposable income. In Finland, changes in youth smoking prevalence from 1977 to 1993 were mainly due to fluctuations in "affordability", that is, the ratio of price to pocket money. ${ }^{136}$

The scope for raising taxes may be limited by smuggling, ${ }^{12,137}$ and high prices may have regressive effects on disadvantaged groups. ${ }^{14}$ Nevertheless, there is a strong case for investing health sector funds in presentations to finance ministries on the use of fiscal policy to promote health. ${ }^{138,139}$

\section{THE CREATION OF UNPAID PUBLICITY AND}

\section{MEDIA ADVOCACY}

Unpaid publicity is defined as any form of media coverage which does not involve payment for space or broadcast time, although it may require a substantial investment of resources. Examples include the deliberate creation of news coverage around the latest scientific findings, stories urging government action or attacking the tobacco industry, human interest stories about cancer victims, educational features, photo calls, or events such as No Smoking Day. ${ }^{140}$

Major media "health scares" can have a direct effect on smokers, ${ }^{33}$ resulting in short term declines in per capita consumption of up to $5 \% .^{141}$ Little is known about its direct influence on youth, but UK smokers of 16-19 years of age are particularly active participants in the annual No Smoking Day. ${ }^{142}$

However, the most important reason for investing resources in the creation of publicity lies in its effects on public opinion, and ultimately, on decision makers. Studies in communications theory suggest that the repeated expression of a particular opinion in the media causes its supporters to voice their beliefs more openly, while opponents fall silent for fear of social isolation - so creating a "spiral of silence". ${ }^{143}$

News stories can therefore have measurable effects on public opinion, ${ }^{144,145}$ and also on elected politicians and their senior advisers. ${ }^{146}$ This important group, while denying any personal susceptibility to media influence, is often concerned about its presumed effect on others $^{147}$ (the "third person effect"148).

Systematic use of the mass media to advance public policy initiatives is known as "media advocacy", 149,150 as in the case of the US group "Mothers against drunk driving" (MADD), set up in 1980 . Its success in forcing the issue onto the public agenda through media advocacy was associated with the passage of substantial legislation to control drunk driving in the $1980 \mathrm{~s}$ - although there was no significant increase in drunk driving in the USA during this period. ${ }^{151}$

In Finland, smoking prevalence declined among all age groups in the 1970s, during a period of intense public discussion on the health hazards of tobacco. This was stimulated

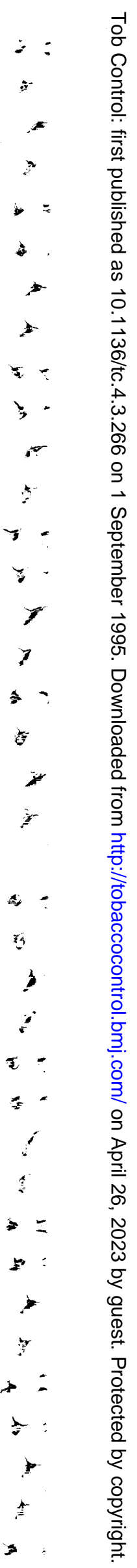

\% 
Table 1 Review of major options for the reduction of teenage smoking prevalence

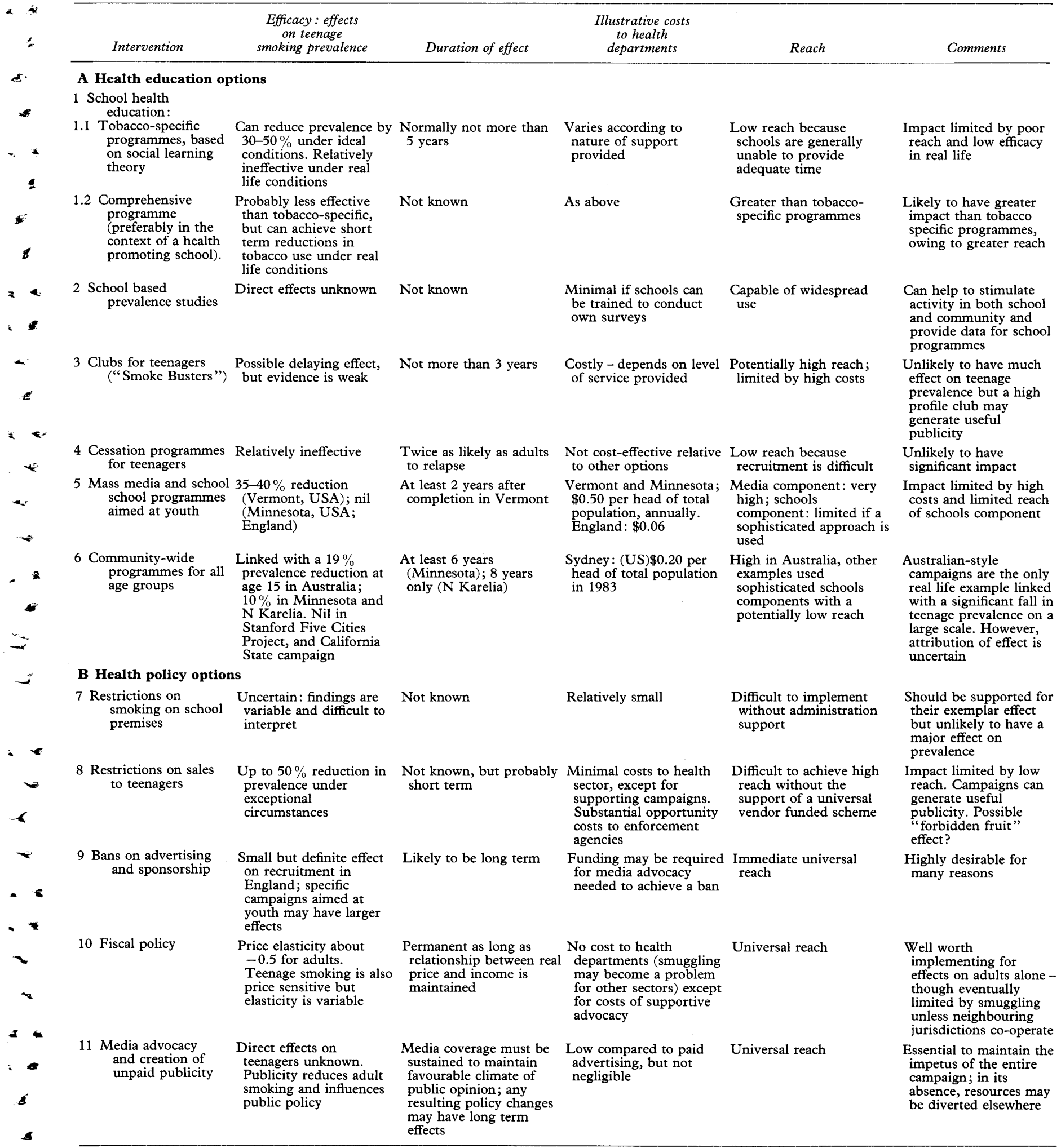

by parliamentary debates relating to the passage of the 1977 Tobacco Act to ban advertising, among other measures. ${ }^{152}$ However, by 1980 , female and adolescent smoking started to rise; later, illegal sales to 14 year olds and smoking in schools increased, and the Act was both weakened and ineffectively implemented. ${ }^{153}$

A major cause of these surprising events was the disappearance of smoking and health as an issue from the media limelight-owing to complacency following the passage of the
Tobacco Act. ${ }^{27,153}$ Lack of media support was also cited as a contributory cause of the termination of the Minnesota state prevention programme. ${ }^{154}$

Costs

The costs of media advocacy and the creation of unpaid publicity are considerably lower than paid mass campaigns, but are not negligible. An agenda setting event such as No- 
Smoking Day costs about $\$ 0.02$ per head of total population annually in the United Kingdom. ${ }^{101}$ An effective long term strategic programme of media advocacy for a population of about 50 million ideally requires an annual investment of at least $\$ 0.5$ million - though occasional opportunistic bursts of publicity can be achieved for much less.

\section{Conclusions}

Although there are few published studies on this subject, indirect evidence suggests that media advocacy is fundamental to the survival of any long term national programme to reduce smoking prevalence. Its principal contribution lies in its potential to influence decision makers and thereby ensure the allocation of adequate resources and the adoption of effective policies.

\section{Discussion}

It will be obvious from this review that there are no "magic bullets" for the prevention of teenage smoking, and that large gaps in our understanding remain. However, some general conclusions can be drawn (table 1 ).

On the whole, the broader the approach, the greater the likelihood of success; teenage smoking prevalence is likely to fall fastest in countries where funds are available for broadly based community campaigns, supported by favourable fiscal policy, restrictions on smoking at work and in schools, and a ban on tobacco advertising. ${ }^{3,4}$ Even then, as the Californian State campaign has shown, success with youth is not guaranteed.

Isolated interventions aimed specifically at young people are less likely to have lasting results. Schools acting alone cannot be expected to change long held community norms, ${ }^{155}$ such as tolerance of smoking, because society generally expects teachers to transmit prevailing values unchanged. ${ }^{156}$ They are also unlikely to be effective with high risk youth $^{157}$ in view of the association between smoking and alienation from school. ${ }^{71}$

Paid advertising, as in the Vermont project, may give better results with this important group. However, the generalisability of the Vermont initiative is limited by its high cost. At $\$$ US 0.50 per head of total population, and after allowing for economies of scale, a Vermont-style campaign for the whole of the USA would cost around $\$ 100$ million annually for a single year group of teenagers only. In proportion to population, this is equivalent to the total annual budget (US \$5-10 million) for both prevention and cessation in Australia. ${ }^{158}$

Table 2 Recommendations for the cost-effective investment of health sector funds :

- Priority should be given to the creation of a climate of public opinion favourable to the achievement and maintenance of effective tobacco control policies

Activities intended to reduce teenage smoking should only be conducted as part of a broader programme for all age roups, and not in isolation

Preference should be given to interventions likely to influence the greatest number of individuals; reach is more important than efficacy in determining investment priorities
If funds of that magnitude are available, much greater benefit to public health could be achieved by investing in programmes for all age groups, rather than youth alone (table 2 ). ${ }^{33}$

Historically, programmes aimed primarily at youth have been funded because of their popularity with the public, ${ }^{4}$ and in the belief that because most smokers take up smoking by age $18,{ }^{159}$ any success will be permanent. ${ }^{4}$ Because even the best programmes only delay recruitment, and up to $10 \%$ of smokers may be recruited as young adults, ${ }^{160}$ this is unlikely to be the case.

Finally, as the example of Finland has shown, the effective use of media advocacy is essential for the creation of public opinion favourable to effective tobacco control policies. In its absence, hard won successes may eventually be lost as resources are diverted to competing priorities.

In most Western countries, the generally flat or even rising trends in teenage smoking prevalence are difficult to explain in view of the continuing decline among adults, and the commitment of substantial resources to prevention. It is possible that the falls in teenage prevalence from the 1960 s to the 1980 s were due to success in reaching those who were the most susceptible to education. ${ }^{157}$

It is also possible that the more non-smoking has become the norm among adults, the more attractive it is to teenagers, especially girls, seeking a visible symbol of non-conformity. ${ }^{17,18}$ Whatever the explanation, further declines in teenage smoking may be difficult to achieve with the range of interventions available at present. We can only hope that youth smoking prevalence will ultimately follow the downward adult trend in Western countries (assuming it continues), as it is difficult to imagine a world where only teenagers smoke.

This paper was originally commissioned by Professor Witold Zatoriski for presentation at a UICC/WHO conference on Cancer Prevention for Central and Eastern European Public Health Leaders in Tobacco Control, Warsaw, Poland, in September 1993. Earlier drafts were much improved by comments from reviewers, and colleagues in the United Kingdom, USA, and Australia. Thanks are also due to Sally Todd for drafting advice, Rodney Amis for literature to Sally and Karan Demm advice, Rodney Amis for literature retrieval, the authors, who write in a personal capacity, are solely responsible for the opinions expressed in this paper.

1 Glynn TJ, Greenwald P, Mills SM, Manley MW. Youth tobacco use in the United States- problem, progress goals, and potential solutions. Prev Med 1993; 22: 568-75.

2 Department of Health (UK). The health of the nation: a strategy for health in England. London: HMSO 1992

3 Royal College of Physicians of London. Smoking and the young. London: RCP, 1992

4 US Department of Health and Human Services. Preventing tobacco use among young people. A report of the Surgeon General. Atlanta, Georgia: Public Health Service, General. Atlanta, Georgia: Public Health Service, Smoking and Health, 1994. (US Government Printing Office No S/N 017-001-00491-0.

5 Office of Population Censuses and Surveys (OPCS). General household survey: cigarette smoking (in Great Britain) 1972-1992. London: HMSO, 1994.

6 Smith C, Wold B, Moore L. Health behaviour research with adolescents: a perspective from the WHO crossnational health behaviour in school - aged children study. Health Promotion fournal of Australia 1992; 2: 41-4.

7 Escobedo LG, Marcus SE, Holtzman D, Giovino GA Sport participation, age at smoking initiation, and the risk of smoking among US high school students. $¥ A M A$ 1993; 269: 1391-5.

8 Thomas M, Holroyd S, Goddard E Smoking amon secondary school children in 1992. OPCS for the Department of Health. London: HMSO, 1993. 

9 McNeill AD. The development of dependence on smoking

10 Goddard E. Why children start smoking. OPCS for the Department of Health. London: HMSO, 1990. (For summary with commentaries, see: Goddard E. Why children start smoking. $B r \mathcal{F}$ Addict 1992; 87: 17-25).

11 Conrad KM, Flay BR, Hill D. Why children start smokin cigarettes: predictors of onset. $B r \mathcal{F}$ Addict 1992; 87: 1711-24.

12 La Vecchia C, Scarpino V. Smoking in Italy, 1987-90. Tobacco Control 1993; 2: 231-6.

13 Rudat K, Speed M, Ryan H. Tomorrow's young adults. London: Health Education Authority, 1992

14 Marsh A, McKay S. Poor smokers. London: Policy Studies Institute 1994

15 Minagawa K-E, Nishioka N, Kawabata T, Takahashi H, Mochizuki Y, Nozu Y, et al. Tobacco use among Japanese schoolchildren: results from preliminary study of Japan adolescent smoking survey (JASS). Health Promotion International 1992; 7: 37-51.

16 Swan AV, Melia RJW, Fitzsimmons B, Breeze E, Murray M. Why do more girls than boys smoke cigarettes? Health Educ f 1989 ; 48: 59-64.

17 Piepe A, Cattermole B, Charlton P, Morey F, Morey J, Yerrell P. Girls, smoking and self-esteem - the adolescent context. Health Educ f 1988 ; 47: 83-5.

18 Oakley A, Brannen J, Dodd K. Young people, gender and smoking in the United Kingdom. Health Promotion International 1992; 7: 75-88.

19 Banwell CL, Young D. Rites of passage: smoking and the construction of social identity. Drug Alcohol Rev 1993; 12: $377-85$.

20 Pirie PL, Murray DM, Luepker RV. Gender differences in cigarette smoking and quitting in a cohort of young adults. Am F Public Health 1991; 81: 324-27.

21 Halek C, Kerry S, Humphrey H, Crisp AH, Hughes JM. Relationship between smoking, weight and attitudes to weight in adolescent schoolgirls. Postgrad Med F 1993; 69: $100-6$.

22 Stanton WR, Silva PA, Oei TPS. Prevalence of smoking in a Dunedin sample followed from age 9 to 15 years. NZ Med F 1989; 102: 637-9.

23 Baan B. Prevention of smoking among young children in Holland: education and changing attitudes. Lung 1990 Suppl: $320-6$.

24 Bynner JM. The young smoker... smoking among schoolboys. London: HMSO, 1969.

25 Lee L, Gilpin EA, Pierce JP. Changes in the patterns of initiation of cigarette smoking in the United States: 1950, 1965 and 1980. Cancer Epidemiol Biomarkers Prevent 1993 ; 2 : 593-7.

$26 \mathrm{IJF}$ Institut für Jugendforschung. Die Entwicklung der Drögenaffinitat jugendlicher. Report for the Bundeszentrale fur gesündheitliche Aufklärung, Köln, Germany, 1992.

27 Rimpelä M, Aarø LE, Rimpelä $\mathrm{AH}$. The effect of tobacco sales promotion on initiation of smoking - experiences from Finland and Norway. Scand $\mathcal{F}$ Soc Med 1993; suppl 49: 1-19.

28 Smith C, Nutbeam D, Moore L, Roberts C, Catford J. Current changes in smoking attitudes and behaviours among adolescents in Wal

29 Sweanor D. Excise taxes and preventing tobacco use in young people. World Smoking and Health 1992; 17: 9-12.

30 Hill DJ, White VM, Williams RM, Gardner GJ. Tobacco and alcohol use among Australian secondary school students in 1990. Med $\mathcal{F}$ Aust 1993; 158: 228-34.

31 Bauman KE, Ennett SE. Tobacco use by black and white adolescents: the validity of self-reports. Am F Public Health 1994; 84: 394-8.

32 Velicer WF, DiClemente CC. Understanding and intervening with the total population of smokers. Tobacco vening with the total
Control 1993; 2 : $95-6$.

33 Reid DJ, Killoran AJ, McNeill AD, Chambers JS. Choosing the most effective health promotion options for reducing a nation's smoking prevalence. Tobacco Control 1992; 1: 185-97.

34 Chapman $\mathrm{S}$. Unravelling gossamer with boxing gloves: problems in explaining the decline in smoking. $B M F$ 1993; 307: 429-32.

35 Thompson EL. Smoking education programs, 1960-1976. Am f Public Health 1978; 68: 250-7.

36 Bandura A. Social learning theory. Englewood Cliffs, New Jersey: Prentice-Hall, 1977.

37 Murray DM, Pirie P, Luepker RV, Pallonen U. Five- and six-year follow up results from four seventh-grade smoking prevention strategies. F Behav Med 1989; 12: 207-18.

38 Flay BR, Koepke D, Thomson SJ, Santi S, Best JA, Brown KS. Six-year follow-up of the first Waterloo school smoking prevention trial. Am F Public Health 1989; 79: 1371-6.

39 Best JA, Thomson SJ, Santi SM, Smith EA, Brown KS. Preventing cigarette smoking among schoolchildren. Annu Rev Public Health 1988; 9: 161-201.

40 Glynn T. Essential elements of school-based smoking prevention programs: research results. $\mathcal{f}$ School Health 1989; 59: 181-8. 41 Bellew W, Wayne D. Prevention of smoking among
schoolchildren: review of research and recommended actions. Health Educ $\mathcal{F} 1991 ; 50$ : 3-8.

42 Bruvold WH. A meta-analysis of adolescent smoking prevention programs. Am 7 Public Health 1993; 83: 872-80.

43 McAlister A, Perry C, Killen J, Slinkard LA, Maccoby N. Pilot study of smoking, alcohol, and drug abuse prevention. Am f Public Health 1980; 70: 719-21.

44 Klepp K-I, Tell GS, Vellar OD. Ten-year follow-up of the Oslo youth study smoking prevention program. Prev Med $1993 ; 22: 453-62$

45 Eiser JR, Morgan M, Gammage P. Social education is good for health. Educ Res 1988; 30: 20-5.

46 Abernathy TJ, Bertrand LD. Preventing cigarette smoking among children: results of a four year evaluation of the PAL program. Can $\mathcal{F}$ Pub Health 1992; 83: 226-9.

47 Lloyd DM, Alexander HM, Callcott R, Dobson AJ, O'Conell DL, Leeder SR. Cigarette smoking and drug use in school children. III. Evaluation of a smoking prevention programme. Int $\mathcal{f}$ Epidemiol 1983; 12: 51-8.

48 prevention programme. Int $\mathcal{f}$ Epidemiol 1983 ; 12 : $51-8$. year follow-up results of an adolescent smoking preyear follow-up results of an adolescent smoking prePublic Health 1990; 80: 78-9.

49 Kozlowski LT, Coambs WB, Ferrence RG, Adlaf EM. Preventing smoking and drug use: let the buyers beware and the interventions be apt. Can $\mathscr{F}$ Public Health 1989; 80: 452-6.

50 Cleary PD, Hitchcock JL, Semmer N, Flinchbaugh LJ, Pinney JM. Adolescent smoking: research and health policy. Milbank $Q 1988 ; 66$ : 137-71.

51 Rogers EM. Diffusion of innovations, 3rd ed. New York: The Free Press, 1983.

52 Murray DM, Perry CL, Griffin G, Harty KC, Jacobs DR, Schmid L, et al. Results from a statewide approach to adolescent tobacco use prevention. Prev Med 1992; 21: 449-72.

53 Nutbeam D, Macaskill P, Smith C, Simpson JM, Catford J. Evaluation of two school smoking programmes under normal classroom conditions. BMf 1993; 306: 102-7.

54 Jessor R, Jessor SL. Problem behavior and psychosocial development : a longitudinal study of youth. New York: Academic Press, 1977.

55 Connell DB, Turner RR, Mason EF. Summary of findings of the School Health Education Evaluation: health promotion effectiveness, implementation and costs. $f$ School Health 1985; 55: 316-21.

56 Gillies PA, Wilcox B. Reducing the risk of smoking amongst the young. Public Health 1984; 98: 49-54.

57 Walter HJ, Vaughan RD, Wynder EL. Primary prevention of cancer among children: changes in cigarette smoking and diet after six years of prevention. $\mathcal{F}$ Natl Cancer Inst 1989 ; 81 : 995-9.

58 Ross JG, Gold RS, Lavin AT, Errecart MT, Nelson GD. Design of the Teenage Health Teaching Modules evaluation. $\mathcal{f}$ School Health $1991 ; 61: 21-5$.

59 Nelson GD, Cross FS, Kolbe L. Introduction: Teenage Health Teaching Modules evaluation. $\mathcal{F}$ School Health $1991 ; 61: 4$.

60 Errecart MT, Walberg HJ, Ross JG, Gold RS, Fieldler JL, Kolbe LJ. Effectiveness of the Teenage Health Teaching Modules. F School Health 1991; 61: 10-14.

61 Gold RS, Parcel GS, Walberg HJ, Luepker RV. Portnoy, B, Stone EJ. Summary and conclusions of the THTM evaluation: the expert work group perspective. $f$ School Health 1991; 61: 39-42.

62 Ross JG, Luepker RV, Nelson GD, Saavedra P, Hubbard BM. Teenage Health Teaching Modules: impact of BM. Teenage Health Teaching Modules: impact of teacher training on implementation and

63 Murray M, Kiryluk S, Swan AV. School characteristics and adolescent smoking. Results from the MRC/Derbyshire Smoking Study $1974-8$ and from a follow up in 1981. $\mathcal{F}$ Epidemiol Community Health 1984; 38: 167-72

64 Pierce JP, Farkas A, Evans N, Berry C, Choi W, Rosbrook $\mathrm{B}$, et al. Tobacco use in California 1992: a focus on Department of Health Services, 1993.

65 Clarke VA, White V, Hill D, Borland R. School structural and policy variables associated with student smoking. Tobacco Control 1994; 3: 339-46.

66 Charlton A. Evaluation of a family-linked smoking programme in primary schools. Health Educ $\mathcal{F} 1986 ; 45$ : $140-4$.

67 Sunseri AJ, Alberti KM, Kent ND, Schoenberger JA, Sunseri JK, Amuwo S, et al. Reading, demographic, social and psychological factors related to pre-adolescent smoking and non-smoking behaviours and attitudes. $\mathcal{F}$ School Health 1983; 53: 257-63.

68 Aarø LE, Bruland E, Hauknes A, Löchsen PM. Smoking among Norwegian schoolchildren 1975-80. III. The effect of anti-smoking campaigns. Scand $\mathcal{F}$ Psychol 1982; 23: 277-83.

69 Perry CL, Murray DM, Griffin G. Evaluating the statewide dissemination of smoking prevention curricula: factors in dissemination of smoking prevention curricula: factors

70 Rohrbach LA, Graham JW, Hansen WB. Diffusion of a school-based substance abuse prevention program: predictors of program implementation. Prev Med 1993; 22: $237-60$.

71 Nutbeam D, Aarø LA. Smoking and pupil attitudes towards school: the implications for health education with young people. Health Educ Res 1991 ; 6: 415-21.

72 Silvestri B, Flay BR. Smoking education: comparison of practice and state-of-the-art. Prev Med 1989; 18 257-66.

73 Wall U, Digiusto E, Lamb C. Smoking prevention in 
western Sydney schools. Health Promotion 7 Aust 1995 $5: 40-5$

74 Tobacco Education Oversight Committee. Toward a tobacco-free California. Submitted to the California State Legislature. Sacramento: Department of Health, 1993.

75 Calman ALH, Carmichael S, Deans HG, Calman KC. Development of a primary school health education programme with special emphasis on the prevention of cigarette smoking. Health Educ $\mathcal{f} 1985 ; 44$ : 65-9.

76 Taioli E, Wynder EL. Effect of the age at which smoking begins on frequency of smoking in adulthood. $N$ Engl $\mathscr{F}$ Med 1991; 325: 968-9.

77 Ershler J, Leventhal H, Fleming R, Glynn K. The quitting experience for smokers in sixth through twelfth grades. Addict Behav 1989;14: 365-78.

78 WHO/UNESCO/UNICEF. Comprehensive school health education; suggested guidelines for action. Geneva: WHO,

79 Gillies P, Elwood JM, Cust G. An adolescent smoking survey in Trent, and its contribution to health promotion Health Educ $\mathcal{F} 1987$; 46: 19-22.

80 Edwards R, Watson P. The Airedale schools survey: providing local information on smoking prevalence in schoolchildren. Health Educ $\mathcal{F}$ 1994; 53: 52-7.

81 Nelson SC, Budd RJ, Eiser JR, Morgan M, Gammage P, Gray $E$. The Avon prevalence study: a survey of cigarette smoking in secondary school children. Health Educ $\mathcal{F}$ $1985 ; 44: 12-15$.

82 Hansen WB, Graham JW. Preventing alcohol, marijuana, and cigarette use among adolescents: peer pressure resistance training versus establishing conservative resistance training versus establishi
norms. Prev Med 1991: 20: 414-30.

83 Rawbone RG, Guz A. Cigarette smoking among secondary school children, 1975-79. Arch Dis Child 1982; 57 school

84 Jacobs J. Smoking in schools. $\mathcal{F} R$ Soc Health February

85 Stevenson-Robb Y. Smoke Busters. F Inst Health Educ $1989 ; 27: 193-6$.

86 van Teijlingen ER, Friend JAR. Smoking habits of Grampian school children and an evaluation of the Grampian Smoke Busters campaign. Health Educ Res 1993; 8: 97-108.

87 van Teijlingen ER, Friend JAR. Smoking prevalence of Grampian schoolchildren. Aberdeen: University of Aberdeen, 1993

88 Brannan J, Dodd K, Oakley A, Storey P. Young people, health and family life. Buckingham, UK: Open University Press, 1994.

89 Semmer NK, Cleary PD, Dwyer JH, Fuchs R, Lippert P. Psychosocial predictors of adolescent smoking in two German cities: the Berlin-Bremen study. $M M W R$ 1986; 36: 35-105.

90 Pallonen Ũ, Murrày DM̄, Schmid L, Pirie P, Luepker RV. Patterns of self-initiated smoking cessation among young adults. Health Psychol 1990; 9: 418-26.

91 Altman DG, Flora JA, Fortmann SP, Farquhar JW. The cost-effectiveness of three smoking cessation programs. Am $\mathcal{f}$ Public Health 1987; 77 : 162-5.

92 Digiusto $E$. Pros and cons of cessation interventions for adolescent smokers at school. In: Richmond R, ed. Interventions for smokers - an international perspective. Baltimore: Williams and Wilkins 1994: 107-36.

93 Chen TTL, Winder AE. Teachers' perceptions related to smoking education between 1973 and 1982. ₹ Drug Educ $1985 ; 15: 125-38$.

94 Townsend J, Wilkes H, Haines A, Jarvis M. Adolescent smokers seen in general practice: health, lifestyle, physical measurements, and response to anti-smoking advice. $B M \mathcal{F} 1991 ; 303$ : 947-50.

95 Reid DJ. Prevention of smoking among schoolchildren: recommendations for policy development. Health Educ $\mathcal{F}$ $1985 ; 44: 3-12$.

96 Bauman KE, LaPrelle J, Brown JD, Koch GG, Padgett CA. The influence of three mass media campaigns on variables related to adolescent cigarette smoking: results of a field experiment. Am $\mathcal{f}$ Public Health 1991; 81: 597-604.

97 Flynn BS, Worden JK, Secker-Walker RH, Pirie PL, Badger GJ, Carpenter JH, et al. Mass media and school
interventions for cigarette smoking prevention: effects interventions for cigarette smoking prevention: effects two years

98 Harty K. Animals and butts : Minnesota's media campaign against tobacco. Tobacco Control 1993; 2: 271-4.

99 Murray DM, Prokhorov AV, Harty KC. Effects of a statewide antismoking campaign on mass media messages and smoking beliefs. Prev Med 1994; 23: 54-60.

100 Woods C. Anti-smoking education: working with the teenage magazine market. Health Educ $\mathcal{F} 1991$; 50: 19-26.

101 Buck D, Godfrey C. Helping smokers give up-guidance for purchasers on cost effectiveness. London: York University Centre for Health Promotion, for the Health Education Authority, 1994

102 Perry CL, Kelder SH, Murray DM, Klepp K-I. Community wide smoking prevention: long-term outcomes of the Minnesota Heart Health Program and the class of 1989 study. Am f Public Health 1992; 82: 1210-6.

103 Winkleby MA, Fortmann SP, Rockhill B. Cigarette smoking trends in adolescents and young adults: the Stanford Five City Project. Prev Med 1993; 22: 325-34. 104 Pierce JP, Evans N, Farkas AJ, Cavin SW, Berry C,
Kramer M, et al. Tobacco use in California : an evaluation of the Tobacco Control Program, 1989-93. Report to the Californian Dept of Health Services. La Jolla: University of California, San Diego, 1994 .

105 Pierce JP, Dwer T, Frape G, Chamberlain A, Burke N. Evaluation of the Sydney Quit for Life antismoking campaign. Part 1 . Achievement of intermediate goals. Med f A A st 1986; 144 : 341-4.

106 Hill DJ, White VM, Gray NJ. Australian patterns of tobacco smoking in 1989. Med f Aust 1991; 154: 797-801.

107 Hill D. Prevalence of cigarette smoking among Australian secondary school students in 1993: preliminary report. Centre for Behavioural Research in Cancer, Anti-Cancer Council of Victoria, 1994.

108 Cooreman J, Perdrizet S Smoking in teenagers: some psychological aspects. Adolescence $1980 ; 15: 581-8$.

109 Pentz M, Brannon BR, Charlin VI, Barrett. EJ MacKinnon DP, Flay BR. The power of policy: the
, relationship of smoking policy to adolescent smoking. relationship of smoking policy to adol

110 Crow CS. Smoking areas in school grounds. Are we encouraging children to smoke? Adolescent Health Care $1984 ; 5: 117-9$

111 Wasserman J, Manning WG, Newhouse JP, Winkler JD. The effect of excise taxes and regulations on cigarette smoking. F Health Econ 1991 ; 10: 43-64.

112 US Department of Health and Human Services: National Cancer Institute. Major local tobacco ordinances in the United States. Washington, DC, 1993. NIH publication 93-3532.

113 Health Education Authority. Smoking policies in schools. London: Health Education Authority, 1993.

114 Stradling R. Smoking policies in schools: guidelines for development-evaluation report. London: National Foundation for Educational Research (NFER) for the HEA, 1994.

115 Altman DG, Foster V, Rasenick-Douss L, Tye JB Reducing the illegal sale of cigarettes to minors. $\mathcal{F} A M A$ $1989 ; 261: 80-3$.

116 Naidoo J, Platts C. Smoking prevention in Bristol: getting maximum results using minimum resources. Health Educ F 1985; 44: 39-42

117 Feighery E, Altman DG, Shaffer G. The effects of combining education and enforcement to reduce tobacco sales to minors. A study of four Northern California communities. F $A M A$ 1991; 266: 3168-71.

118 Altman D, Carol J, Chalkley C, Cherner J, DiFranza J Feighery E, et al. Report of the Tobacco Policy Research Study Group on access to tobacco products in the United States. Tobacco Control 1992; 1(suppl): S45-51.

119 Jason LA, Ji PY, Anes MD, Birkhead SH. Active enforcement of cigarette control laws in the prevention of cigarette sales to minors. FAMA 1991; 266: 3159-61.

120 DiFranza JR, Carlson RP, Caisse RE. Reducing youth access to tobacco. Tobacco Control 1992; 1: 58

121 Hinds MW. Impact of a local ordinance banning tobacco sales to minors. Public Health Rep 1992; 107:355-8.

122 Radecki TE, Zdunich CD. Tobacco sales to minors in 97 US and Canadian communities. Tobacco Control 1993; 2: 300-6.

123 Davis RM. Reducing youth access to tobacco. $7 A M A$ 1991; 266: 3186-7.

124 Carol J. It's a good idea to criminalise the purchase and possession of tobacco by minors - NOT! Tobacco possession of tobacco

125 Department of Health Economics and Operational Research Division. Effect of tobacco advertising on tobacco consumption : a discussion reviewing the evidence ("Smee Report" ). London: Department of Health, 1992.

126 Pierce JP, Lee L, Gilpin EA. Smoking initiation by adolescent girls, 1944 through 1988: an association with targeted advertising. $\mathscr{F} A M A$ 1994; $23: 608-11$.

127 DiFranza JR, Richards JW, Paulman PM, Wolf-Gillespie, Fletcher C, Jaffe RD, et al. RJR Nabisco's cartoon camel promotes Camel cigarettes to children. FAMA 1991; 266: 3149-53.

128 Hastings GB, Ryan H, Teer P, MacKintosh AM. Cigarette advertising and childrens' smoking: why Reg was withdrawn. BMF 1994; 309: 933-7.

129 Cunningham $R$, Kyle $K$. The case for plain packaging. Tobacco Control 1995; 4: 80-6.

130 Amos A. Youth and style magazines: hooked on smoking? Health Visitor 1993; 66: 91-3.

131 Wright $\mathrm{T}$. Images of smoking in film. Report to the HEA. London: Health Education Authority, 1993.

132 Hazan AR, Lipton HL, Glantz SA. Popular films do not reflect current tobacco use. Am F Public Health 1994; 84: $998-1000$

133 Dykes J. Taste of the future for tobacco men. South China Morning Post, 16 August, 1989: 22-23.

134 Townsend J, Roderick P, Cooper J. Cigarette smoking by socioeconomic group, sex and age: effects of price,

135 income, and health publicity. $B M \mathscr{J} 1994 ; 309 ; 923-7$. ( The impact of cigarette excise taxes and smoking among children and adults. Summary report of an NCI expert panel. Bethesda, MD: National Cancer Institute, 1993.

136 Rimpelä A, Rimpelä M, Pohjanpaa K, Karvonen S, Siivola M. Protection of children from the tobacco products, Finland 1977 - 1993. Helsinki: Ministry of Social Affairs and Health: Reports 1993: 5 (In Finnish).

137 Joossens L, Raw M. Smuggling and cross border shopping of tobacco in Europe. BMF $1995 ; \mathbf{3 1 0}$ : 1393-7.

138 Medhora R, Phillips A, de Savigny D. The economics of 


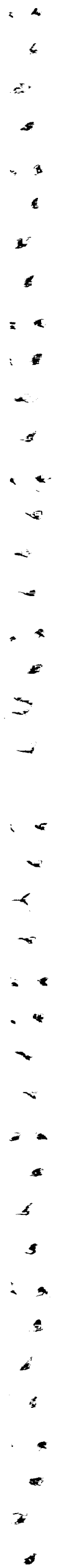

tobacco: enabling the transition. Tobacco Control 1994; 3: 295-6.

139 Barnum $\mathrm{H}$. The economic burden of the global trade in tobacco. Tobacco Control 1994; 3: 358-61.

140 Musk AW, Shean R, Walker N, Swanson M. Progress on smoking control in Western Australia. BMF 1994; 308 : 395-8.

141 Bosanquet N, Trigg A. A smoke free Europe in the Year 2000: wishful thinking or realistic strategy? Chichester, UK: Carden Publications, 1991 .

142 McGuire C. Pausing for breath: a review of No Smoking Day research, 1984-1991. London: Health Education Authority for the No Smoking Day Committee, 1992.

143 Nöelle-Neumann E. The theory of public opinion: the concept of the spiral of silence. In: Anderson JA, ed. Communications yearbook/14. Newbury Park, California: Sage Publications for the International Communications Association, 1991.

144 Tichenor PJ, Wackman DB. Mass media and community public opinion. Am Behav Scientist 1973; 16: 593606.

145 Iyengar S, Peters MD, Kinder DR. Experimental demonstrations of the "not-so-minimal" consequences of television news programs. Am Polit Sci Rev 1982; 76: 848-58.

146 Graber DA. The impact of media research on public opinion studies. In: Whitney DC, Wartella E, Windahl opinion studies. In: Whitney DC, Wartella E, Windahl Park, California: Sage Publications, 1982: 555-64.

147 Cook FL, Tyler TR, Goetz EG, Gordon MT, Protess D, Leff DR, et al. Media and agenda setting: effects on the public, interest group leaders, policy makers and policy. Public Opin $Q 1983 ; 47: 16-35$.

148 Davison WP. The third-person effect in communication. Public Opin $O 1983 ; 47: 1-15$

149 National Cancer Institute. Media strategies for smoking control: Guidelines. Bethesda, Maryland: National Cancer Institute, 1989. (NIH publication No 89-3013.) 150 Chapman S, Lupton D. The fight for public health: principles and practice of media advocacy. London: BMJ Publishing Group, 1994.

151 Backer TE, Rogers EM, Sopory P. Designing health communications: what works? Newbury Park, California: Sage Publications, 1992

152 Pekurinen $M$. The demand for tobacco products in Finland. Br f Addict 1989; 84: 1183-92.

153 Rimpelä A. Critical analysis of the Finnish Tobacco Act: implementation and legitimacy 1977-89. Tobacco Control 1992; 1 : 285-92.

154 Cummings KM. An obituary: complacency claims the life of a model tobacco programme. Tobacco Control 1993; 2: 270 .

155 Nutbeam D. Exposing the myth - what schools can and cannot do to prevent tobacco use by young people. Promotion Educ 1995; ii: 11-14.

156 Shamai S, Coambs RB. The relative autonomy of schools and educational interventions for substance abuse prevention, sex education and gender stereotyping. $A d o$ lescence $1992 ; 27$ : 757-70.

157 Glynn TI, Anderson DM, Schwarz BA. Tobacco-use reduction among high-risk youth: recommendations of an NCI expert advisory panel. Prev Med 1991; 20: 279-91.

158 Holman CDJ, Corti B, Donovan RJ, Dawes VP. Tobacco control and health expectancy in Australia. Tobacco Control 1993; $2: 195-200$.

159 US Centers for Disease Control. Differences in the age of smoking initiation between blacks and whites - United States. MMWR 1991; 40: 754-7.

160 Hill D, Borland R. Adults' accounts of onset of regular smoking: influences of school, work, and other settings. Public Health Rep 1991; 106: 181-5.

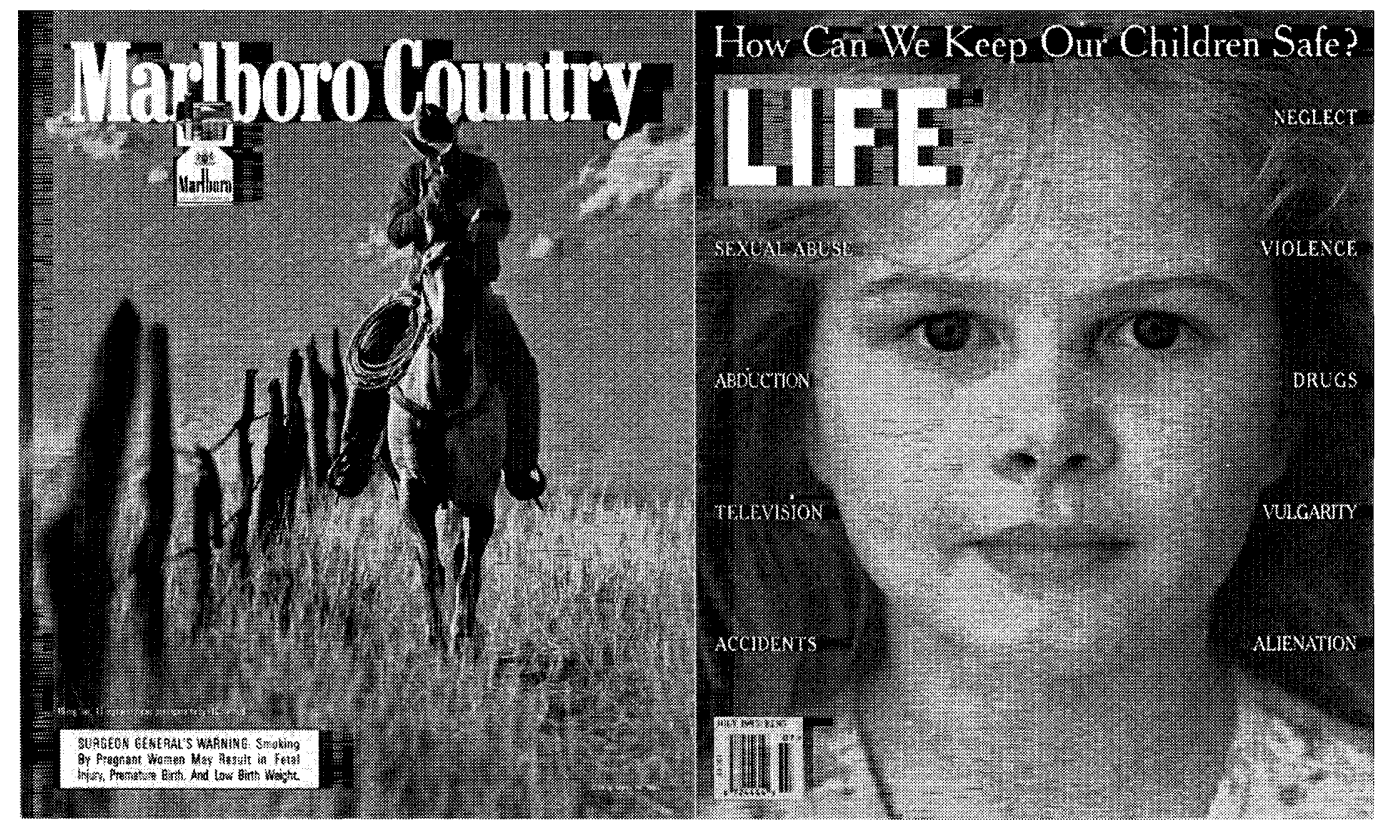

The front and back covers of the fuly 1995 issue of Life magazine. Submitted by Daniel $\mathcal{F}$ Zaccaro. 